\title{
UPAYA PENINGKATAN KEMAMPUAN ANALISIS DAN PRESTASI BELAJAR SISWA PADA MATERI KELARUTAN DAN HASIL KALI KELARUTAN KELAS XI SMA NEGERI 2 SURAKARTA DENGAN PENERAPAN MODEL PEMBELAJARAN PROBLEM BASED LEARNING
}

\author{
Guguh Nomilasari, Bakti Mulyani*, dan Sri Retno Dwi Ariani \\ Program Studi Pendidikan Kimia, FKIP, Universitas Sebelas Maret, Surakarta, Indonesia \\ * Keperluan korespondensi, telp : 081227611216, email: baktimulyani@staff.uns.ac.id
}

\begin{abstract}
ABSTRAK
Tujuan penelitian ini untuk meningkatkan kemampuan analisis dan prestasi belajar siswa kelas XI MIPA 4 SMA Negeri 2 Surakarta pada materi Kelarutan dan Hasil Kali Kelarutan dengan penerapan model pembelajaran Problem Based Learning. Penelitian ini merupakan Penelitan Tindakan Kelas (PTK) dengan dua siklus. Tiap siklus terdiri 4 tahap yaitu perencanaan, pelaksanaan, observasi, dan refleksi. Subjek penelitian adalah siswa kelas XI MIPA 4 SMA Negeri 2 Surakarta tahun ajaran 2017/2018. Sumber data dari guru dan siswa, teknik pengumpulan data berupa tes,observasi,angket dan wawancara. Teknik analisis adalah deskriptif kualitatif. Hasil penelitian menunjukkan bahwa pada materi kelarutan dan hasil kali kelarutan dengan menerapkan model pembelajaran Problem Based Learning dapat meningkatkan kemampuan analisis dan prestasi belajar siswa. Pada siklus I persentase kemampuan analisis siswa dengan kategori tinggi sebesar $67,65 \%$ dan pada siklus II mencapai $85,29 \%$. Kemudian hasil prestasi belajar pada aspek pengetahuan, siklus I mencapai persentase ketercapaian sebesar $70,59 \%$ sedangkan pada siklus II meningkat menjadi $88,24 \%$. Pada aspek sikap, siswa dengan kategori sikap baik dan sangat baik mencapai persentase $61,76 \%$ dan $38,24 \%$ pada siklus I, sedangkan siklus II mengalami peningkatan yaitu $26,47 \%$ dan $73,53 \%$. Pada aspek keterampilan persentase ketercapaian pada siklus I yaitu sebesar $82,35 \%$.
\end{abstract}

Kata Kunci: Kelarutan dan Hasil Kelarutan, Kemampuan Analisis, Penelitian Tindakan Kelas, Prestasi Belajar, Problem Based Learning

\section{PENDAHULUAN}

Pendidikan adalah usaha sadar dan terencana untuk mewujudkan suasana belajar dan proses pembelajaran agar peserta didik secara aktif mengembangkan potensi dirinya untuk memiliki kekuatan spiritual keagamaan, pengendalian diri, kepribadian, kecerdasan, akhlak mulia, serta keterampilan yang diperlukan dirinya, masyarakat, bangsa dan negara[1]

Kurikulum 2013 diterapkan pada mata pelajaran kimia. Salah satu karakteristik ilmu kimia adalah sebagian besar konsep-konsepnya bersifat abstrak, seperti struktur atom, ikatan kimia dan konsep asam-basa menurut Kean \& Middlecamp[2]
Selain bersifat abstrak materi kimia juga memerlukan kemampuan analisis untuk mendukung proses belajar materi yang bersifat abstrak dan konkrit.

Kimia adalah salah satu cabang ilmu pengetahuan yang penting dan sangat memungkinkan bagi peserta didik untuk memahami apa yang terjadi di sekitar mereka. Karena topik kimia umumnya saling terkait atau berdasarkan pada materi yang terstruktur dan berasal dari lingkungan sekitar. Sehingga kimia dibuktikan sebagai mata pelajaran yang sulit bagi banyak siswa.[3]

Penemuan lain yaitu pada rendahnya prestasi belajar siswa kelas XI MIPA 4 SMA Negeri 2 Surakarta. 
Tabel 1. Data Nilai Rata-rata Ulangan Harian Semester I Kelas XI MIPA 4

\begin{tabular}{ccc}
\hline Materi & $\begin{array}{c}\text { Nilai } \\
\text { Rata-rata } \\
\text { UH }\end{array}$ & $\begin{array}{c}\text { Persentase } \\
\text { ketuntasan }\end{array}$ \\
\hline Hidrokarbon & 59,39 & $11,76 \%$ \\
Termokimia & 61,26 & $17,65 \%$ \\
Laju Reaksi & 63,82 & $26.47 \%$ \\
Kesetimbangan & 67,32 & $44,12 \%$ \\
Kimia & & \\
\hline
\end{tabular}

Berdasarkan observasi dan wawancara teridentifikasi beberapa permasalahan yang terjadi selama proses belajar mengajar. Berikut beberapa permasalahannya:

1. Proses pembelajaran yaitu penggunaan pendekatan, model dan metode yang kurang sesuai untuk karakter materi yang disampaikan

2. Siswa kurang banyak berlatih soalsoal sementara di kelas hanya mendengar penjelasan dari guru.

3. Sumber belajar hanya berasal dari guru berupa slide power point.

4. Prestasi belajar mata pelajaran kimia kelas XI MIPA 4 realatif masih rendah.

5. Siswa sering lupa dengan pelajaran dan konsep yang telah dipelajari sebelumnya.

6. Kemampuan analisis siswa relatif masih rendah

Materi kelarutan dan hasil kali kelarutan memerlukan kemampuan awal siswa yaitu penguasaan materi kimia yang sebelumnya telah dipelajari terutama kesetimbangan kimia dan asam basa. Selain itu rumus dalam materi ini bersifat abstrak sehingga untuk mempermudah mempelajari dapat dikaitkan dengan kehidupan sehari-hari. Sementara itu penyampaian materi pada kurikulum 2013 diharuskan melibatkan atau terkait dengan permasalahan kehidupan sehari-hari. Maka perlu pendekatan dan model pembelajaran yang sesuai.

Problem Based Learning (PBL) adalah pendekatan berpusat pada instruksional yang memberdayakan peserta didik untuk melakukan penelitian, mengintegrasikan teori dan praktik, dan menerapkan pengetahuan dan keterampilan untuk mengembangkan solusi yang tepat untuk masalah yang diberikan[3]

Langkah-langkah model pembelajaran PBL, yaitu orientasi siswa pada masalah, mengorganisasi siswa untuk belajar, memandu menyelidiki secara mandiri atau kelompok, mengembangkan dan menyajikan hasil kerja, menganalisis dan mengevaluasi hasil pemecahan masalah. Dalam langkahlangkah model pembelajaran PBL ini terdapat bagian dimana siswa harus memecahkan masalah yang terkait dengan kehidupan sehari-hari mereka. Pemecahan masalah tersebut merupakan bagian dari pembangunan konsep oleh siswa sendiri, sehingga PBL dapat meningkatkan kemampuan analisis siswa.

Penerapan pembelajaran berbasis masalah dapat meningkatkan kemampuan berpikir siswa. Hal ini dapat dilihat melalui adanya perubahan pada pola pikir siswa berdasarkan tingkatan kognitif. Kemampuan bertanya dan menjawab siswa meningkat dari kemampuan berpikir tingkat rendah (pengetahuan, pemahaman, dan aplikasi) menjadi berpikir tingkat tinggi (analisis, sintesis dan evaluasi)[4]

Untuk meningkatkan prestasi belajar dan kemampuan analisis siswa serta untuk mengatasi permasalahan dalam penyampaian materi kimia, maka salah satu cara yang bisa dilakukan adalah dengan menerapkan model pembelajaran Problem Based Learning pada materi kelarutan dan hasil kali kelarutan kelas XI SMA Negeri 2 Surakarta.

\section{METODE PENELITIAN}

Penelitian Tindakan Kelas (PTK) ini dilaksanakan di SMA Negeri 2 Surakarta. Penelitian ini terdiri dari dua siklus yang masing-masing siklus terdiri dari 4 tahap, yaitu perencanaan (planning), tindakan (acting), pengamatan (observing), dan refleksi (reflecting)[5]. Subjek penelitian adalah siswa kelas XI MIPA 4 SMA Negeri 2 Surakarta tahun pelajaran 2017/2018. Sumber data dari guru dan siswa dengan menggunakan teknik 
pengumpulan data berupa tes, observasi, angket dan wawancara. Teknik analisis pada penelitian ini adalah deskriptif kualitatif yang dilakukan dari awal pengumpulan data sampai pengumpulan data terakhir. Data hasil penelitian dianalisis secara kualitatif menurut Miles dan Huberman, dimana analisa terdiri dari tiga alur kegiatan yang terjadi secara bersamaan yaitu reduksi data, penyajian data dan penarikan kesimpulan/verifikasi. Pada penelitian ini digunakan teknk triangulasi data untuk memeriksa validitas data dalam penelitian. triangulasi teknik pengumpulan data dilakukan untuk menguji kredibilitas data dengan mengecek data dari berbagai sumber, cara atau teknik serta waktu[6].

\section{HASIL DAN PEMBAHASAN}

Penellitian tindakan kelas ini menerapkan model pembelajaran Problem Based Learning pada materi kelarutan dan hasil kali kelarutan. Dalam pelaksanaannya siswa akan memiliki kemampuan membangun pengetahuannya sendiri melalui aktivitas belajar, sehingga siswa memiliki kemampuan memecahkan masalah sementara guru hanya sebagai fasilitator. Penerapan model pembelajaran Problem Based Learning diharapkan dapat meningkatkan kemampuan berpikir siswa terutama kemampuan analisis. Melalui pemecahan masalah pada langkah dalam penerapan model pembelajaran Problem Based Learning akan mengasah kemampuan analisis siswa sehingga akan meningkat. Dengan meningkatnya kemampuan analisis siswa diharapkan prestasi belajar siswa pada materi kelarutan dan hasil kali kelarutan juga ikut meningkat.

\section{Siklus I}

\section{a. Perencanaan Tindakan}

Pada tahap ini peneliti dan guru mempersiapkan beberapa perangkat penelitian seperti silabus, Rencana Pelaksanaan Pembelajaran (RPP), Instrumen pengetahuan, Instrumen Kemampuan Analisis, Instrumen Sikap dan Instrumen Keterampilan. Instrumen tersebut disesuaikan dengan model pembelajaran Problem Based Learning berdasarkan persetujuan dan diskusi guru dengan peneliti.

\section{b. Pelaksanaan Tindakan}

Materi yang akan dipelajari pada siklus I yaitu kesetimbangan kelarutan, proses pelarutan, kelarutan dan hasil kali kelarutan, memprediksi terbentuknya endapan dan pengaruh ion senama terhadap kelarutan.

Kegiatan pembelajaran dari awal sampai akhir pertemuan siklus I mengalami perkembangan. Terutama perkembangan aktivitas siswa yang beradaptasi dengan penerapan model pembelajaran Problem Based Learning.

Pada kegiatan inti siswa diorientasikan pada permasalahan dalam hal ini berupa demonstrasi, melaksanakan ekperimen di lab serta menjawab soal-soal diskusi. Setelah itu siswa diberikan kesempatan untuk merencanakan strategi pemecahan masalah dan memecahkan masalah dimana pada tahap ini siswa dapat menggunakan berbagai sumber pengetahuan atau bertanya pada guru dan teman apabila menemui kesulitan dalam mengerjakan soal-soal diskusi.

Hasil diskusi kelompok kemudian disajikan didepan kelas sementara kelompok lain memberikan tanggapan. Pada akhir kegiatan siswa bersama guru melakukan refleksi proses pembelajaran dan menyamakan persepsi siswa untuk memberikan penguatan dalam mengambil kesimpulan hasil pembelajaran bersama-sama.

Pada pertemuan terakhir siklus I dilaksanakan evaluasi untuk mengetahui pemahaman siswa pada materi kelarutan dan hasil kali kelarutan. Pelaksanaan sudah baik namun beberapa indikator yang ditetapkan masih belum tercapai

\section{c. Observasi}

Pada tahap ini dilakukan observasi oleh peneliti dan beberapa observer untuk mengamati kegiatan siswa selama pembelajaran dan untuk menilai aspek sikap dan keterampilan siswa ketika proses pembelajaran siklus I berlangsung. 


\section{d. Hasil Tindakan Siklus I}

Hasil tindakan siklus I dibandingkan dengan indikator keberhasilan siswa yang telah ditetapkan maka ketercapaian target siklus I dapat dilihat pada tabel 2 .

Tabel 2. Ketercapaian Target Siklus I

\begin{tabular}{cccc}
\hline $\begin{array}{c}\text { Aspek yang } \\
\text { dinilai }\end{array}$ & $\begin{array}{c}\text { Target } \\
(\%)\end{array}$ & $\begin{array}{c}\text { Keter- } \\
\text { capaian } \\
(\%)\end{array}$ & Kriteria \\
\hline $\begin{array}{c}\text { Kemampuan } \\
\text { Analisis }\end{array}$ & 75 & 67,65 & $\begin{array}{c}\text { Belum } \\
\text { Tercapai } \\
\text { Belum }\end{array}$ \\
Pengetahuan & 75 & 70,59 & $\begin{array}{c}\text { Tercapai } \\
\text { Sikap }\end{array}$ \\
Keterampilan & 75 & 100,00 & $\begin{array}{c}\text { Tercapai } \\
\text { Tercapai }\end{array}$ \\
\hline
\end{tabular}

\section{e. Refleksi}

Hasil penelitian yang diperoleh menunjukkan bahwa pada pembelajaran siklus I terdapat dua aspek penilaian yang belum mencapai target yang telah ditentukan. Yaitu aspek pengetahuan dan aspek kemampuan analisis. Hal ini dapat terjadi karena siswa belum terbiasa belajar menggunakan model pembelajaran yang baru. Sehingga menyebabkan pemahaman kurang maksimal. Selain itu keberlangsungan proses pembelajaran kurang maksimal karena siswa kurang sadar akan pentingnya proses pembelajaran tersebut. Diantaranya masih banyak siswa yang melakukan kegiatan lain diluar kegiatan belajar dan kurang bertanggungjawab dan kerja sama dalam kontribusinya untuk menyelesaikan soalsoal diskusi. Dari uraian diatas maka perlu dilaksanakan tindakan siklus II untuk memperbaiki dan meningkatkan persentase ketercapaian hasil belajar siswa. Pada siklus II tidak dilaksanakan tindakan untuk aspek keterampilan karena telah memenuhi target pada siklus I.

\section{Siklus II}

\section{a. Perencanaan Tindakan}

Pada pembelajaran siklus II perbaikan difokuskan pada aspek kemampuan analisis dan pengetahuan karena kedua aspek tersebut belum mencapai target. Perbaikan aspek pengetahuan didasarkan pada materi dengan indikator kompetensi yang belum tuntas pada siklus I.
Beberapa tindakan yang perlu dilakukan pada siklus II diantaranya yaitu membuat kelompok menjadi lebih heterogen berdasarkan hasil dari siklus I, guru memberikan motivasi pada siswa agar lebih giat belajar dan bersungguhsungguh mengikuti pembelajaran, guru mengefektifkan waktu pelaksanaan pembelajaran, dan memberikan bimbingan yang lebih terhadap siswa yang belum tuntas agar lebih mudah memahami dalam memecahkan masalah. Demikian diharapkan dapat memperoleh hasil yang lebih baik dan dapat mencapai target yang telah ditentukan pada sikllus II.

\section{b. Pelaksanaan Tindakan}

Perbaikan aspek pengetahuan didasarkan pada materi dengan indikator kompetensi yang belum tuntas pada siklus I. Indikator yang belum tuntas yaitu menentukan $\mathrm{pH}$ larutan dari harga Kspnya, memprediksi terbentuknya endapan berdasarkan $K s p$ dan menjelaskan pengaruh penambahan ion senama dalam larutan.

\section{c. Observasi}

Observasi dilakukan untuk menilai aspek sikap siswa selama proses pembelajaran siklus II berlangsung. Tahap observasi ini dilakukan oleh peneliti bersama beberapa observer lainnya.

\section{d. Hasil Tindakan Siklus II}

Berdasarkan indikator keberhasilan siswa yang telah ditetapkan maka ketercapaian target siklus II dapat dilihat pada tabel 3.

Tabel 3. Ketercapaian Target Siklus II

\begin{tabular}{cccl}
\hline $\begin{array}{c}\text { Aspek } \\
\text { yang dinilai }\end{array}$ & $\begin{array}{c}\text { Target } \\
(\%)\end{array}$ & $\begin{array}{c}\text { Keter- } \\
\text { capaian } \\
(\%)\end{array}$ & Kriteria \\
\hline Kemampuan & 75 & 85,29 & Tercapai \\
Analisis & 75 & 88,24 & Tercapai \\
Pengetahuan & 75 & 100,00 & Tercapai \\
\hline Sikap & 75 &
\end{tabular}

Dapat dilihat pada tabel 3 bahwa kemampuan analisis dan aspek pengetahuan pada siklus II telah mencapai target yang ditetapkan. Sehingga dapat dikatakan bahwa penerapan model pembelajaran Problem Based Learning pada materi kelarutan dan hasil kali 
kelarutan dapat meningkatkan ketercapaian target dan berhasil memenuhi target yang ditentukan.

Berdasarkan hasil penelitian yang diperoleh telah sesuai dengan penelitian sebelumnya yang menyatakan bahwa penerapan model pembelajaran Problem Based Learning dapat meningkatkan prestasi belajar siswa kelas XI IPA $[7,8,9]$. Selain itu penerapan model pembelajaran Problem Based Learning selain meningkatkan prestasi belajar ternyata dapat meningkatkan kemampuan analisis[10]

\section{Perbandingan Hasil Tindakan Antarsiklus}

Pada penelitian ini pada masingmasing siklus terdapat penilaian kemampuan analisis, aspek pengetahuan dan sikap. Sedangkan penilaian aspek keterampilan dilakukan pada siklus I saja sebab telah memenuhi target yang ditentukan.

Berdasarkan hasil penelitian diketahui pada siklus I siswa dengan kemampuan analisis tinggi berjumlah 23 siswa $(67,65 \%)$. Sedangkan siswa dengan kemampuan analisis sedang berjumlah 11 siswa (32,35\%). Perbandingan hasil penilaian kemampuan analisis siklus I dan siklus II dapat dilihat pada Gambar 1.

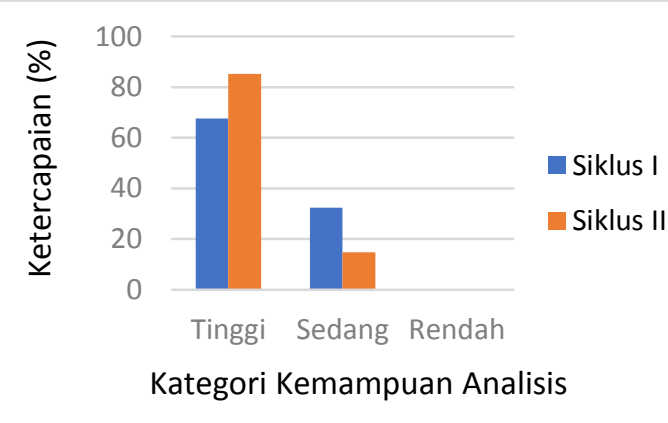

Gambar 1. Perbandingan Persentase Ketercapaian Kemampuan Analisis Siswa

Berdasarkan gambar tersebut diketahui bahwa hasil tes kemampuan analisis siswa pada siklus II mengalami pening-katan dibandingkan dengan siklus I.

Pada hasil tes aspek pengetahuan siswa dapat diketahui terjadi peningkatan pada siklus II dibandingkan dengan siklus I. Dimana pada siklus I sebanyak 24 siswa $(70,59 \%)$ telah mencapai KKM sedangkan pada siklus II diperoleh hasil 30 siswa $(88,24 \%)$ telah mencapai target ketuntasan. Perbandingan hasil tes aspek pengetahuan siswa pada siklus I dan siklus II dapat dilihat pada Gambar 2.

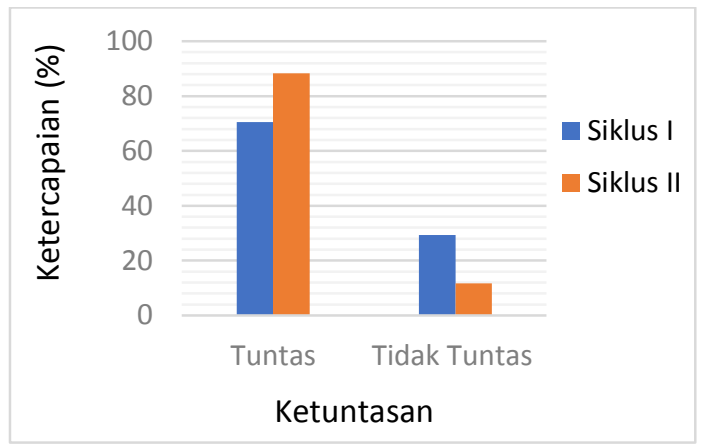

Gambar 2. Perbandingan Persentase Ketercapaian Aspek Pengetahuan Siswa

Hasil penelitian pada aspek sikap didapat dengan melakukan observasi, angket dan wawancara. Pada siklus I diketahui Isebanyak 13 siswa (38,24\%) dengan kategori sikap sangat baik dan 21 siswa $(61,76 \%)$ dengan kategori sikap baik. Pada siklus II diketahui sebanyak 25 siswa (73,53\%) memiliki kategori sikap sangat baik dan 9 siswa $(26,47 \%)$ memiliki kategori sikap baik. Terjadi peningkatan pada siklus II dibandingkan dengan siklus I hasil ini ditunjukkan pada Gambar 3.

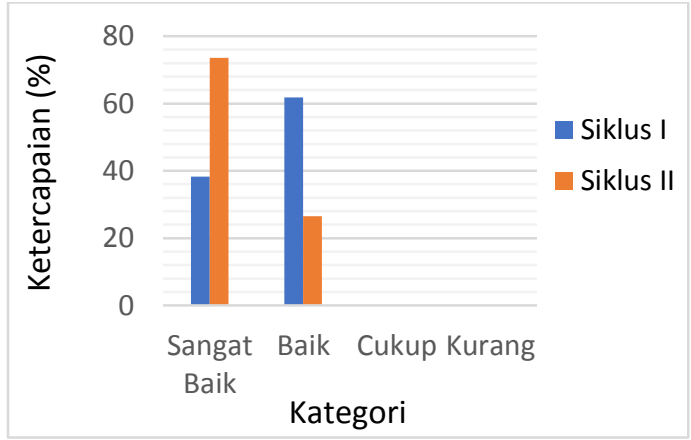

Gambar 3. Perbandingan Persentase Ketercapaian Aspek Sikap Siswa

Selain peningkatan persentase ketercapaian aspek sikap siswa, persentase ketercapaian masing-masing indikator juga mangalami peningkatan 
pada siklus II dibandingkan dengan siklus I. Hal ini dapat dilihat pada gambar 4 .

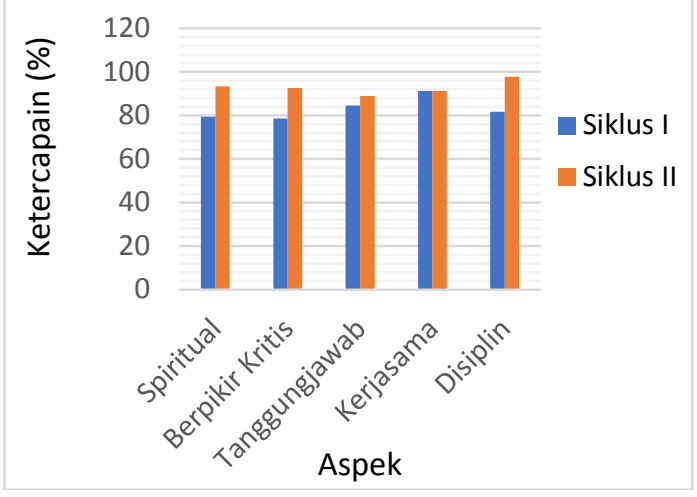

Gambar 4. Perbandingan Persentase Ketercapaian Tiap Aspek Sikap Siswa

Penilaian aspek keterampilan dilaksanakan dengan cara observasi kegiatan presentasi siswa saat berlangsung selama proses pembelajaran. Hasil persentase ketercapaian aspek keterampilan pada siklus I menunjukkan $82,35 \%$ siswa tuntas atau mencapai target yang ditetapkan yaitu $75 \%$ dari total seluruh siswa dikelas dengan memperoleh nilai minimum 75. Sehingga pada siklus II tidak diperbaiki kembali.

\section{KESIMPULAN}

Hasil penelitian menunjukkan bahwa pada materi kelarutan dan hasil kali kelarutan dengan menerapkan model pembelajaran Problem Based Learning dapat meningkatkan kemampuan analisis dan prestasi belajar siswa. Pada siklus I persentase kemampuan analisis siswa dengan kategori tinggi sebesar $67,65 \%$ dan pada siklus II mencapai 85,29\%.

Kemudian hasil prestasi belajar pada aspek pengetahuan, siklus I mencapai persentase ketercapaian sebesar $70,59 \%$ sedangkan pada siklus II meningkat menjadi $88,24 \%$. Pada aspek sikap, siswa dengan kategori sikap baik dan sangat baik mencapai persentase $61,76 \%$ dan $38,24 \%$ pada siklus I, sedangkan siklus II mengalami peningkatan yaitu $26,47 \%$ dan $73,53 \%$. Pada aspek keterampilan persentase ketercapaian pada siklus I yaitu sebesar $82,35 \%$.

\section{UCAPAN TERIMA KASIH}

Penulis mengucapkan terimakasih kepada Bapak Drs. Sutikno, M.M. selaku Kepala Sekolah yang telah memberikan izin penelitian di SMA Negeri 2 Surakarta, kemudian Bapak Drs. H. Wagiman, M.Pd. sebagai guru kimia kelas XI MIPA 4 SMA Negeri 2 Surakarta yang telah membimbing dalam penelitian.

\section{DAFTAR RUJUKAN}

[1] Undang-Undang Republik Indonesia Nomor 20 Tahun 2003 Sistem Pendidikan Nasional. 8 Juli 2003. Lembaran Negara Republik Indonesia Tahun 2003 Nomor 4301. Jakarta.

[2] Indrayani, P. 2013, Jurnal Pendidikan Sains, 1(2), 109-120.

[3] Sirhan, G.,200, Journal of Turkish Science Education, 4(2), 2-20.

[4] Afcariono, M., 2008, Jurnal Pendidikan Inovatif, 3(2), 65-68.

[5] Sutama, 2010, METODE PENELITIAN PENDIDIKAN. Surakarta, Fairuz Media.

[6] Sugiyono, 2013, Metode Penelitian Kombinasi (Mixed Methods), Bandung, Alfabeta.

[7] Agustina, R. P., Ashadi, dan Mulyani, B. , 2017, Jurnal Pendidikan Kimia, 6(2), 144-153.

[8] Desnylasari, E., Mulyani, S., dan Mulyani, B., 2016, Jurnal Pendidikan Kimia, 5(1), 134-142.

[9] Oktaviana, I. A., Saputro, A. N. C., dan Utami, B. 2016 .Jurnal Pendidikan Kimia, 5(1), 143-152.

[10] Sawitri, R. N., Setyowati, W. A. E., \& Mulyani, B., 2015, Jurnal Pendidikan Kimia, 4(4), 103-108. 